\title{
BACTERIOLOGICAL CHANGES OF BURN WOUNDS WITH TIME AND THEIR ANTIBIOGRAM
}

\author{
Rajbahak $\mathbf{S}^{*}$, Shrestha $\mathrm{C}^{*}$, Shrestha $\mathrm{J}^{* *}$ and Singh $\mathrm{A}^{* * *}$ \\ * Central Department of Microbiology, Tribhuvan University, Kathmandu, Nepal. \\ * Consultant Medical Microbiologist, Pathology, Bir Hospital, Kathmandu, Nepal. \\ $* * *$ Head of Central Department of Microbiology, Tribhuvan University, Kathmandu, Nepal.
}

\begin{abstract}
A prospective study was carried out in 42 burn patients admitted in burn unit of Bir Hospital over a period of six months from September 2011 to February 2012 to evaluate time-related changes in aerobic bacterial colonization and their susceptibility pattern. Periodic swabs were taken from the burn wound on $1^{\text {st }}, 2^{\text {nd }}, 3^{\text {rd }}$ and $4^{\text {th }}$ weeks to see the changing pattern of organisms during hospital stay of patients. Wound swabs obtained from the burn patients were subjected to microbiological analysis. The isolates were identified by standard microbiological techniques and their antibiotic susceptibility was determined by using Kirby-Bauer disk diffusion techniques. In the present study burn injury was highest in the age group 25-34 years (28.6\%). Male to female ratio was 1:1.5. Fire was the major cause of burn (78.6\%) followed by scald burn (7.1\%). Among the 168 samples, single organism was isolated in $47.6 \%$ samples and mixed organisms in 39.9\% and no growth in 12.5\%. A total of 215 bacterial species were isolated from 168 samples in which Pseudomonas aeruginosa accounted for the highest percentage $45.6 \%$ followed by Staphylococcus aureus (19.1\%), Acinetobacter spp. (17.7\%) and coagulase negative Staphylococci (CONS) (5.6\%). Gram negative bacteria were the dominating bacteria all over the study period and exhibited lower sensitivity to most of the antibiotic used. Furthermore, $P$. aeruginosa was least sensitive to most antibiotics used. Amikacin was the drug of choice for most Gram negative bacteria and vancomycin was found to be susceptible drug for Gram positive organisms (S. aureus and CONS). Continuous survey and analysis of changing microbial flora and their antibiogram in burn patients help in timely detection and control of spread of infection and also help to review effective antibiotic policies.
\end{abstract}

Keywords: Burn; Burn wounds infection; P. aeruginosa; Antibiotics resistance.

\section{INTRODUCTION}

The skin is an essential component of the nonspecific immune system, protecting the host from potential pathogens in the environment (Chalise et al., 2008). Thermal burns are burn to the skin caused by any external heat source; other types of burn include radiation burns, chemical burns and electrical burns (Chalise et al., 2008; Lawerence and Florencia, 2008). Burns remain a significant public health problem in term of morbidity, long-term disability and mortality throughout the world; especially in economic developing countries (Ekrami and Kalantar, 2007). Despite major advances in the care of burn patients, infectious complications remain an important cause of morbidity and death. Furthermore, wound invasion still represents a major cause of infection in burn intensive care units (Santucci et al., 2003). Burn patients are at a high risk for infection as a result of the nature of the burn injury itself, the immunecompromising effects of burn, prolonged hospital stays and intensive diagnostic and therapeutic procedures (Lari and Alaghehbandan, 2000).
Burn patients have to stay for long period in the hospital and many intravascular and other devices are put in them. Hence they are at greater risk of acquiring hospitalacquired infection. The organisms that predominate as causative agents of burn wound infection in any burn treatment facility change over time. Gram positive organisms are initially prevalent during hospital stay of patients; then gradually become superseded by gram negative opportunists that appear to have a greater propensity to invade (Pruitt 1984). Infection in burn is not only important in being responsible for death but it is also an important factor in the prolongation of hospitalization time and delay in skin grafting. It is therefore essential for every burn institution to determine the time-related changes in predominant flora and antimicrobial sensitivity profile (Ulku et al., 2004).

The data on the changes in microbial profile in burn wound with respect to time are limited. Rapidly emerging nosocomial and community acquired pathogens and the problem of multi-drug resistance necessitates periodic review of isolation patterns and antibiogram in the burn

Author for Correspondence: Anjana Singh, Head,Central Department of Microbiology, Tribhuvan University, Kathmandu, Nepal. E-mail: anjanas67@yahoo.com. 
ward. Although eradication of infection in burn patients is impossible, a well conducted surveillance; infection control and prevention programme can help reduce the incidence, mortality rates, length of hospitalization and associated costs. The present study is undertaken to study the time related change in micro flora in burn wounds of the burn patients from a tertiary care medical hospital.

\section{METHODS}

Samples were collected over a period of six months from September 2011 to February 2012. The microbial colonization of wounds was studied weekly from the date of admission upto the $4^{\text {th }}$ week of hospitalization. Periodic wound swabs were collected at $1^{\text {st }}, 2^{\text {nd }}, 3^{\text {rd }}$, and $4^{\text {th }}$ weeks of hospital stay. So during the period the total number of samples from 42 patients was 168.The sampling procedure included collection of swab from deep area of burn wound site prior to any cleansing. In each sampling procedure, the bandages were removed, the remnants of topical antimicrobial agents were scraped away and the wounds were swabbed before washing and applying new topical antimicrobial agents. Puswere collected by using sterile cotton tipped swabs. Specimens were immediately transferred to sterile test tube. In case of collection of sample from dry surface, swabs were moistened with sterile normal saline. After collection, tubes were plugged properly, labeled and carried promptly to the microbiology laboratory. Of two samples taken from each patient, one was used for Gram stain and other for culture (Collee et al., 1999). All wound swab specimens were inoculated on Blood Agar (BA) plate, MacConkey agar (MA) and Nutrient agar (NA) and incubated at $37^{\circ} \mathrm{C}$ for $18-24$ hours (Benson, 2001; Cheesbrough, 2006). Preliminary identification of bacterial isolates were done using colony morphology and characteristics (like pigmentation, haemolysis pattern on blood agar) and also by Gram staining whenever necessary. Conventional biochemical tests from peptone suspensions of the isolates were performed from primary cultures for final identification of the isolates. In brief, Gram negative rods were identified by performing of a series of biochemical tests, namely: catalase test, oxidase test, oxidative-fermentative (OF) test, methyl-red (MR) test, Voges-Proskauer (VP) test, indole test, motility test, hydrogen sulphide $\left(\mathrm{H}_{2} \mathrm{~S}\right)$ production test, triple sugar iron (TSI) reactions, citrate utilization test, and urease test. Gram-positive cocci were identified based on their preference of growth on BA and NA followed by catalase test, oxidase test, OF test and coagulase test (Benson 2001; Cheesbrough
2006). Mueller Hinton Agar (MHA) was used for determining the sensitivity of bacteria by using KirbyBauer disk diffusion technique (CLSI 2006).

\section{RESULTS AND DISCUSSION}

During the six months of prospective study, the total of 42 patients with a new burn incident were investigated at the burns center. Age wise distribution of patient ranges from 16 to 79 years (mean 38.9, median 33.5, SD 18.9). Incidence of burn was more common in female $(60 \%)$ as compared to male (40\%).Studying the site of burn accident on the body of burn patients, the highest percentage of burn affected was extremities and genitalia 13 (31\%). The total body surface area (TBSA) burn range with $15 \%$ to $90 \% ; 20-39 \%$ burn category included the highest percentage of patients $(50.0 \%)$. Flame burns resulted in $33(78.6 \%)$ cases followed by scald $3(7.1 \%)$, electrical 3 (7.1\%), lightening 2 (4.8\%) and acid $1(2.4 \%)$ burns. Majority of burn patients were third degree (full-thickness) burn 28 (67\%) and second degree (partial-thickness) burn 12 (28\%). First degree burn $2(5 \%)$ accounted for the least number of burn among total patients.

The overall percentage of positive cultures was $87.5 \%$ in comparison to the no growth $12.5 \%$.A total of 215 bacterial isolates were identified from 168 pus swabs: $P$. aeruginosa accounted for the highest percentage 98 (45.6\%) from the burn wounds followed by $S$. aureus 41 (19.1\%) and Acinetobacter spp. 38 (17.7\%). Meanwhile, CONS, Klebsiella spp., E. coli, Proteus spp., Citrobacter spp. and Enterobacter spp. represent the lowest isolated microorganisms and account for $38(17.7 \%)$ isolates. $P$. aeruginosa accounted for the highest percentage $98(45.6 \%)$ from the burn wounds followed by $S$. aureus 41 (19.1\%) and Acinetobacter spp. 38 (17.7\%). Also, P. aeruginosa was dominating bacteria in both single and mixed infections (Table 1).

P. aeruginosa 22 (38.6\%), Acinetobacterspp. 12 (21\%) and $S$. aureus $11(19.2 \%)$ were the most prevalent isolates on $1^{\text {st }}$ week culture (pus 1). There was a slight increase in the number of $P$. aeruginosa $28(50 \%)$ while the number of Acinetobacter spp. 10 (17.8\%) and $S$. aureus $11(19.6 \%)$ remain almost similar from day $1^{\text {st }}$ to $3^{\text {rd }}$ week (pus 3). Acinetobacter spp. $6(13.3 \%)$ and $S$. aureus $6(13.3 \%)$ decreased significantly but P. aeruginosa $26(57.8 \%)$ remained predominating bacteria from $3^{\text {rd }}$ to $4^{\text {th }}$ week (pus 4 ). Klebsiella spp. and E. coli decreases from $3(5.3 \%)$ and $2(3.5 \%)$ to $1(2.2 \%)$ respectively whereas Citrobacter spp., Enterobacter spp. and Proteus spp. were absent at $4^{\text {th }}$ week (pus 4 ) of culture (Table 2). 
Table 1: Prevalence of bacterial isolates with types of infections.

\begin{tabular}{|c|c|c|c|c|c|}
\hline \multirow{3}{*}{ Organisms } & \multicolumn{5}{|c|}{ Types of infection } \\
\hline & \multicolumn{2}{|c|}{ Mixed } & \multirow[t]{2}{*}{ Organisms } & \multicolumn{2}{|c|}{ Single } \\
\hline & No. & $\%$ & & No. & $\%$ \\
\hline P. aeruginosa + Acinetobacter spp. & 19 & 12.9 & P. aeruginosa & 47 & 32.0 \\
\hline$P$. aeruginosa $+S$. aureus & 10 & 6.8 & S. aureus & 20 & 13.6 \\
\hline P. aeruginosa + CONS & 7 & 4.8 & CONS & 3 & 2.0 \\
\hline P. aeruginosa + E. coli & 3 & 2.0 & Acinetobacter spp. & 10 & 6.8 \\
\hline P. aeruginosa + Klebsiella $\mathrm{spp}$. & 4 & 2.7 & Klebsiella spp. & 0 & 0 \\
\hline P. aeruginosa + Citrobacter spp. & 2 & 1.4 & E. coli & 0 & 0 \\
\hline P. aeruginosa + Proteus spp. & 4 & 2.7 & Citrobater spp. & 0 & 0 \\
\hline P. aeruginosa + Enterobacter $\mathrm{spp}$. & 1 & 0.7 & Enterobacter spp. & 0 & 0 \\
\hline P. aeruginosa $+S$. aureus + Klebsiella spp. & 1 & 0.7 & Proteus spp. & 0 & 0 \\
\hline S. aureus + Acinetobacter spp. & 4 & 2.7 & & & \\
\hline S. aureus + CONS & 1 & 0.7 & & & \\
\hline S. aureus + E. coli & 1 & 0.7 & & & \\
\hline S. aureus + Proteus spp. & 1 & 0.7 & & & \\
\hline S. aureus + Klebsiella spp. & 3 & 2.0 & & & \\
\hline Acinetobacter spp. + CONS & 1 & 0.7 & & & \\
\hline Acinetobacter spp. + Enterobacter spp. & 1 & 0.7 & & & \\
\hline Acinetobacter spp. + Citrobacter spp. & 1 & 0.7 & & & \\
\hline Acinetobacter spp. + E. coli & 2 & 1.4 & & & \\
\hline Proteus spp. + E. coli & 1 & 0.7 & & & \\
\hline Total & 67 & 45.6 & & 80 & 54.4 \\
\hline
\end{tabular}

Table 2: Isolation pattern of bacteria from pus culture in different period of time.

\begin{tabular}{|c|c|c|c|c|c|c|c|c|c|}
\hline \multirow[t]{3}{*}{ Organism } & \multicolumn{8}{|c|}{ Time of sampling (week) } & \multirow[t]{3}{*}{ p-value } \\
\hline & \multicolumn{2}{|c|}{ First } & \multicolumn{2}{|c|}{ Second } & \multicolumn{2}{|c|}{ Third } & \multicolumn{2}{|c|}{ Fourth } & \\
\hline & No. & $\%$ & No. & $\%$ & No. & $\%$ & No. & $\%$ & \\
\hline P. aeruginosa & 22 & 38.6 & 22 & 38.6 & 28 & 50.0 & 26 & 57.8 & \\
\hline S. aureus & 11 & 19.2 & 13 & 22.8 & 11 & 19.6 & 6 & 13.3 & \\
\hline CONS & 3 & 5.3 & 2 & 3.5 & 2 & 3.6 & 5 & 11.1 & \\
\hline Acinetobacter spp. & 12 & 21.0 & 10 & 17.5 & 10 & 17.8 & 6 & 13.3 & \\
\hline Klebsiella spp. & 3 & 5.3 & 3 & 5.3 & 1 & 1.8 & 1 & 2.2 & 0.749 \\
\hline E. coli & 2 & 3.5 & 1 & 1.8 & 3 & 5.4 & 1 & 2.2 & \\
\hline Citrobater spp. & 1 & 1.8 & 2 & 3.5 & - & - & - & - & \\
\hline Enterobacter spp. & 1 & 1.8 & 1 & 1.8 & - & - & - & - & \\
\hline Proteus spp. & 2 & 3.5 & 3 & 5.3 & 1 & 1.8 & - & - & \\
\hline Total & 57 & 100 & 57 & 100 & 56 & 100 & 45 & 100 & \\
\hline
\end{tabular}

$P$. aeruginosa was least sensitive to most of the antibiotic used. However, it was found to be highly sensitive to polymyxin $\mathrm{B}$ as it is evident by only $1 \%$ resistance. Similarly, almost all (90-97\%) Acinetobacter spp. was resistant to cotrimoxazol, cefixime and cefotaxime whereas it was more sensitive to amikacin $(71.1 \%)$ and chloramphenicol (63.2\%). In addition, the members of family enterobacteriaceae were found to be sensitive to amikacin, whereas most of them were resistant to cefixime (Table 3 ).

The antibiotic sensitivity pattern of $S$. aureus showed that most isolates were more sensitive to chloramphenicol (80.5\%) and levofloxacin (80.5\%). Similarly, almost all isolates of $S$. aureus were found to be susceptible for vancomycin (99.0\%). On the other hand, CONS were least sensitive to cotrimoxazole $(8.3 \%)$, gentamycin $(16.7 \%)$ whereas no isolate of CONS was resistant to vancomycin. In addition, they offered moderately 
sensitive to levofloxacin (66.7\%) and ciprofloxacin $(58.3 \%)$ (Table 4$)$.

Antimicrobial sensitivity of $P$. aeruginosa recovered from patient's samples was lower than other isolates. $P$. aeruginosa was found to be resistant to most of antimicrobials used. It was found that the sensitivity pattern of most of the antibiotics used desreased from $1^{\text {st }}$ to $4^{\text {th }}$ week of culture and at the end of $4^{\text {th }}$ week, most of the isolates of $P$. aeruginosa were resistant to all antibiotics except polymyxin B. All isolate of $P$. aeruginosa were sensitive to polymyxin B in contrast, no isolates of $P$. aeruginosa was sensitive to cefixime and cotrimoxazole at $4^{\text {th }}$ week of culture (Table 5).
Acinetobacter spp.were least sensitive $(<20 \%)$ to half of the antibiotics during the $1^{\text {st }}$ week of the culture. Also, they were completely resistant to three-fourth of the antibiotics which include gentamycin, cefotaxime, cefixime, cotrimoxazol, ciprofloxacin and levofloxacin at the end of $4^{\text {th }}$ week. Amikacin was the most effective antibiotic for Acinetobacter spp. followed by chloramphenicol (Table 6).

Cefixime was the least effective drug against most of S. aureus isolated from all samples but vancomycin, chloramphenicol and levofloxacin were the effective drugs against most of $S$. aureus from all samples. There was no significant change in sensitivity patterns of antibiotics all over the four weeks (Table 7).

Table 3: Antibiotics sensitivity pattern of Gram negative bacteria.

\begin{tabular}{|c|c|c|c|c|c|c|c|c|c|}
\hline \multirow[t]{2}{*}{ Organisms } & \multicolumn{9}{|c|}{ Antibiotics - No. (\%) } \\
\hline & AK & GEN & CFM & CTX & $\mathbf{C}$ & COT & CIP & $\mathbf{L E}$ & PB \\
\hline $\begin{array}{l}\text { P. aeruginosa } \\
\mathrm{n}=98\end{array}$ & $\begin{array}{l}35 \\
(35.7)\end{array}$ & $\begin{array}{l}14 \\
(14.3)\end{array}$ & $\begin{array}{l}9 \\
(9.2)\end{array}$ & $\begin{array}{l}24 \\
(24.5)\end{array}$ & $\begin{array}{l}22 \\
(22.4)\end{array}$ & $\begin{array}{l}27 \\
(27.6)\end{array}$ & $\begin{array}{l}20 \\
(20.4)\end{array}$ & $\begin{array}{l}20 \\
(20.4)\end{array}$ & $\begin{array}{l}97 \\
(99.0)\end{array}$ \\
\hline $\begin{array}{l}\text { Acinetobacter spp. } \\
\mathrm{n}=38\end{array}$ & $\begin{array}{l}27 \\
(71.1)\end{array}$ & $\begin{array}{l}12 \\
(31.6)\end{array}$ & $\begin{array}{l}1 \\
(2.6)\end{array}$ & $\begin{array}{l}3 \\
(7.9)\end{array}$ & $\begin{array}{l}24 \\
(63.2)\end{array}$ & $\begin{array}{l}2 \\
(5.3)\end{array}$ & $\begin{array}{l}7 \\
(18.4)\end{array}$ & $\begin{array}{l}15 \\
(39.5)\end{array}$ & - \\
\hline $\begin{array}{l}\text { Klebsiella } \text { spp. } \\
\mathrm{n}=8\end{array}$ & $\begin{array}{l}6 \\
(75.0)\end{array}$ & $\begin{array}{l}3 \\
(37.5)\end{array}$ & $\begin{array}{l}1 \\
(12.5)\end{array}$ & $\begin{array}{l}2 \\
(25.0)\end{array}$ & $\begin{array}{l}1 \\
(12.5)\end{array}$ & $\begin{array}{l}3 \\
(37.5)\end{array}$ & $\begin{array}{l}3 \\
(37.5)\end{array}$ & $\begin{array}{l}3 \\
(37.5)\end{array}$ & - \\
\hline $\begin{array}{l}\text { E. coli } \\
\mathrm{n}=7\end{array}$ & $\begin{array}{l}6 \\
(85.7)\end{array}$ & $\begin{array}{l}2 \\
(28.6)\end{array}$ & $\begin{array}{l}1 \\
(14.3)\end{array}$ & $\begin{array}{l}1 \\
(14.3)\end{array}$ & $\begin{array}{l}1 \\
(14.3)\end{array}$ & $\begin{array}{l}3 \\
(42.9)\end{array}$ & $\begin{array}{l}4 \\
(57.1)\end{array}$ & $\begin{array}{l}5 \\
(71.4)\end{array}$ & - \\
\hline $\begin{array}{l}\text { Ctrobacter spp. } \\
\mathrm{n}=3\end{array}$ & $\begin{array}{l}3 \\
(100)\end{array}$ & $\begin{array}{l}3 \\
(100)\end{array}$ & $\begin{array}{l}0 \\
(0)\end{array}$ & $\begin{array}{l}2 \\
(66.7)\end{array}$ & $\begin{array}{l}2 \\
(66.7)\end{array}$ & $\begin{array}{l}1 \\
(33.3)\end{array}$ & $\begin{array}{l}2 \\
(66.7)\end{array}$ & $\begin{array}{l}2 \\
(66.7)\end{array}$ & - \\
\hline $\begin{array}{l}\text { Enterobacter spp. } \\
\mathrm{n}=2\end{array}$ & $\begin{array}{l}2 \\
(100)\end{array}$ & $\begin{array}{l}1 \\
(50)\end{array}$ & $\begin{array}{l}0 \\
(0)\end{array}$ & $\begin{array}{l}1 \\
(50)\end{array}$ & $\begin{array}{l}2 \\
(100)\end{array}$ & $\begin{array}{l}1 \\
(50)\end{array}$ & $\begin{array}{l}1 \\
(50)\end{array}$ & $\begin{array}{l}1 \\
(50)\end{array}$ & - \\
\hline $\begin{array}{l}\text { Proteus spp. } \\
\mathrm{n}=6\end{array}$ & $\begin{array}{l}6 \\
(100)\end{array}$ & $\begin{array}{l}6 \\
(100)\end{array}$ & $\begin{array}{l}2 \\
(33.3)\end{array}$ & $\begin{array}{l}5 \\
(83.4)\end{array}$ & $\begin{array}{l}5 \\
(83.4)\end{array}$ & $\begin{array}{l}4 \\
(66.7)\end{array}$ & $\begin{array}{l}6 \\
(100)\end{array}$ & $\begin{array}{l}6 \\
(100)\end{array}$ & - \\
\hline
\end{tabular}

Table 4: Antibiotic sensitivity pattern of Gram positive bacteria.

\begin{tabular}{lllll}
\hline Antibiotics & \multicolumn{2}{l}{ S. aureus $(\mathbf{n = 4 1 )}$} & CONS (n= 12) & \% \\
\cline { 2 - 5 } & No. & \% & No. & 41.7 \\
\hline Amikacin & 14 & 34.5 & 5 & 16.7 \\
Gentamicin & 17 & 41.5 & 2 & 41.7 \\
Cefixime & 9 & 22.0 & 5 & 41.7 \\
Cefotaxime & 21 & 51.2 & 5 & 33.3 \\
Chloramphenicol & 33 & 80.5 & 4 & 8.3 \\
Co-trimoxazole & 15 & 36.6 & 1 & 58.3 \\
Ciprofloxacin & 25 & 61.0 & 7 & 66.7 \\
Levofloxacin & 33 & 80.5 & 8 & 41.7 \\
Erythromycin & 22 & 53.7 & 5 & 100.0 \\
Vancomycin & 40 & 97.6 & 12 & 25.0 \\
Oxacillin & 19 & 46.3 & 3 & \\
\hline
\end{tabular}


Table 5: Antibiotic sensitivity pattern of $P$. aeruginosa.

\begin{tabular}{|c|c|c|c|c|c|}
\hline \multirow[t]{4}{*}{ Antibiotics } & \multicolumn{5}{|c|}{ Time of sampling (week) } \\
\hline & First & Second & Third & Fourth & Total \\
\hline & $\mathrm{n}=\mathbf{2 2}$ & $\mathrm{n}=\mathbf{2 2}$ & $\mathrm{n}=\mathbf{2 8}$ & $n=26$ & $\mathrm{n}=98$ \\
\hline & No. (\%) & No. (\%) & No. (\%) & No. $(\%)$ & No. (\%) \\
\hline Amikacin & $10(45.5)$ & $10(45.5)$ & $9(32.1)$ & $6(23.1)$ & $35(35.7)$ \\
\hline Gentamicin & $4(18.2)$ & $5(22.7)$ & $3(10.7)$ & $2(7.3)$ & $14(14.3)$ \\
\hline Cefixime & $4(18.2)$ & $4(18.2)$ & $1(3.6)$ & $0(0)$ & $9(9.2)$ \\
\hline Cefotaxime & $7(31.8)$ & $6(27.3)$ & $6(21.4)$ & $5(19.2)$ & $24(24.5)$ \\
\hline Chloramphenicol & $9(40.9)$ & $7(31.8)$ & $6(21.4)$ & $4(15.4)$ & $26(26.5)$ \\
\hline Co-trimoxazole & $8(36.4)$ & $19(86.4)$ & $0(0)$ & $0(0)$ & $27(27.6)$ \\
\hline Ciprofloxacin & $6(27.3)$ & $6(27.3)$ & $3(10.7)$ & $5(19.2)$ & $20(20.4)$ \\
\hline Levofloxacin & $4(18.2)$ & $9(40.9)$ & $4(14.3)$ & $5(19.2)$ & $22(22.4)$ \\
\hline Polymixin B & $22(100)$ & $22(100)$ & $27(96.4)$ & $26(100)$ & $97(99.0)$ \\
\hline
\end{tabular}

Table 6: Antibiotic sensitivity pattern of Acinetobacter spp.

\begin{tabular}{llllll}
\hline Antibiotics & \multicolumn{3}{c}{ Time of sampling (week) } \\
\cline { 2 - 5 } & First & Second & Third & Fourth & Total \\
& n=12 & n=10 & n=10 & n=6 & n= 38 \\
& No. (\%) & No. (\%) & No. (\%) & No. (\%) & No. (\%) \\
\hline Amikacin & $7(58.3)$ & $8(80.0)$ & $8(80.0)$ & $4(66.3)$ & $\mathbf{2 7}(\mathbf{7 1 . 1})$ \\
Gentamicin & $4(33.3)$ & $4(40.0)$ & $4(40.0)$ & $0(0)$ & $\mathbf{1 2}(\mathbf{3 1 . 6})$ \\
Cefixime & $0(0)$ & $0(0)$ & $1(10.0)$ & $0(0)$ & $\mathbf{2 ( 5 . 3 )}$ \\
Cefotaxime & $1(8.3)$ & $1(10.0)$ & $1(10.0)$ & $0(0)$ & $\mathbf{3 ( 7 . 9 )}$ \\
Chloramphenicol & $9(75.0)$ & $6(60.0)$ & $7(70.0)$ & $2(33.3)$ & $\mathbf{2 4}(\mathbf{6 3 . 2})$ \\
Co-trimoxazole & $1(8.3)$ & $1(10.0)$ & $0(0)$ & $0(0)$ & $\mathbf{2}(\mathbf{5 . 3})$ \\
Ciprofloxacin & $2(16.7)$ & $3(30.0)$ & $2(20.0)$ & $0(0)$ & $\mathbf{7 ( 1 8 . 4 )}$ \\
Levofloxacin & $6(50.0)$ & $6(60.0)$ & $3(30.0)$ & $0(0)$ & $\mathbf{1 5}(\mathbf{3 9 . 5})$
\end{tabular}

Table 7: Antibiotic sensitivity pattern of $\boldsymbol{S}$. aureus.

\begin{tabular}{|c|c|c|c|c|c|}
\hline \multirow[t]{4}{*}{ Antibiotics } & \multicolumn{5}{|c|}{ Time of sampling (week) } \\
\hline & First & Second & Third & Fourth & Total \\
\hline & $\mathrm{n}=\mathbf{1 1}$ & $n=13$ & $\mathrm{n}=\mathbf{1 1}$ & $n=6$ & $n=41$ \\
\hline & No. $(\%)$ & No. $(\%)$ & No. $(\%)$ & No. $(\%)$ & No. $(\%)$ \\
\hline Amikacin & $3(27.3)$ & $5(38.5)$ & $3(27.3)$ & $3(50.0)$ & $14(34.1)$ \\
\hline Gentamicin & $7(63.6)$ & $3(23.1)$ & $5(45.5)$ & $2(33.3)$ & 17 (41.5) \\
\hline Cefixime & $2(18.2)$ & $3(23.1)$ & $3(27.3)$ & $1(16.7)$ & $9(22.0)$ \\
\hline Cefotaxime & $6(54.5)$ & $6(46.2)$ & $5(45.5)$ & $4(66.7)$ & $21(51.2)$ \\
\hline Chloramphenicol & $9(81.8)$ & $10(76.9)$ & $9(81.8)$ & $5(83.3)$ & $33(80.5)$ \\
\hline Co-trimoxazole & $4(36.4)$ & $4(30.8)$ & $4(36.4)$ & $3(50.0)$ & $15(36.6)$ \\
\hline Ciprofloxacin & $7(63.6)$ & $7(53.8)$ & $7(63.6)$ & $3(50.0)$ & 25 (61.0) \\
\hline Levofloxacin & $8(72.7)$ & $11(84.6)$ & $8(72.7)$ & $5(83.3)$ & $33(80.5)$ \\
\hline Vancomycin & $10(91.0)$ & $13(100)$ & $11(100)$ & $6(100)$ & 40 (97.6) \\
\hline Oxacillin & 7 (63.6) & $5(38.5)$ & $4(36.6)$ & $3(50.0)$ & $19(46.3)$ \\
\hline
\end{tabular}


In this study an increase burn number among female $(58.5 \%)$ compared to male $(41.5 \%)$ is observed. This may be attributed to the facts that female in Nepal mostly spend their time in kitchen which increases risks of burn accidents. This is in agreement with similar study in Iran (Panjeshahin et al, 2001) and in contradict with studies from Iran (Alaghehbandan et al., 2001) and Palestine (Silfen et al., 2000) in which males were the victims of burns more frequently than females. Extremities and genitalia were the most common sites of burn in Nepal, which may be due to the cultural habit of wearing more cloths especially females and the cloths made of easily flammable cotton. Flame burn $(78.6 \%)$ was the major cause of burn accidents followed by scald (7.1\%) and electrical (7.1\%). This may be explained based on the facts that many families of Nepal use poor quality kerosene lamps for lightening; kerosene or open wood fires for cooking and warming as they cannot afford safer heating and lighting devices and stoves. This finding was correlated with other study in Iran (Panjeshahin et al., 2001).

Infection with one or more organisms was present in $87.5 \%$ cases in this study. This result was similar to the study conducted in Bangladesh (Saha et al., 2011). The high infections may be due to the cross contamination of the bacteria within or between the patients through contact, air or lack of filtration of air in the burn ward. $P$. aeruginosa was the most common isolate from burn wound culture which coincides with previous reports (Agnihotri et al., 2004; Nasser et al., 2003; Singh et al., 2003) but is in contrast to other studies which report $S$. aureus as predominant organism (Komolafe et al., 2003; Lesseva and Hadjiiski, 1996). The difference may be because of the disparity in sampling procedure i.e. in this study there was periodic sampling but that was a cross sectional. Also half of the burn patients were referred from other hospitals after few days stayed.

Gram negative bacteria continued to become the dominant isolates in all four weeks. This finding is in contrast with the studies done in Turkey (Erol et al., 2004) and Nepal (Chalise et al., 2008). Prevalence of $P$. aeruginosa in the burn wards may be due to the fact that organism thrives in a moist environment (Atoyebiet al., 1992). S. aureus (19.2\%)was the third most predominant organism after Acinetobacter spp (21\%) in the first week which decreased gradually to $13.3 \%$ in fourth week of the hospitalization while CONS increased from 5.3\% to $11.1 \%$ during those period. Several studies have consistently suggested that CONS should be considered a significant pathogen in both burn patients and critically ill surgical patients (Vindenes and Bjerknes, 1995).

Increasing antimicrobial resistance among burn wound isolates is a matter of concern, with limited treatment options available for multidrug-resistant strains (Agnihotori et al., 2004). Gram negative organisms were least sensitive to most of the antibiotics used. Amikacin $(52.5 \%)$ was found to be most effective antimicrobial agent for Gram negative bacteria. The result was similar to the other studies in Brazil (Macedo and Santos, 2005) and Iran (Bojary Nasrabadi and Hajia, 2012). Gram positive bacteria exhibited least sensitive to cefixime (26.4\%) and cotrimoxazole $(30.2 \%)$ while they were highly sensitive to vancomycin $(98.8 \%)$. Cefixime and cotrimoxazole were found to be least effective drugs for both Gram negative bacteria and Gram negative bacteria rendering them ineffective for use.

$P$. aeruginosa was least sensitive to cotrimoxazol, chloramphenicol, cefixime, ciprofloxacin, levofloxacin and gentamycin. The sensitivity pattern gradually decreased from $1^{\text {st }}$ week to $4^{\text {th }}$ week of the culture which may be due to the ability of Pseudomonas to adapt the hospital environment or improper treatment therapy. Polymyxin B was found to be highly sensitive (99\%) against Pseudomonas. Similar least sensitivity of antibiotics in Pseudomonas has been reported in Hunt and Purdue (1992). Also, other non-enterobacteriaceae like Acinetobacter spp. showed low levels of sensitivity to most antibiotics, as also shown in another study (Guggenheim et al., 2009). Almost all isolates of Acinetobacter spp. were completely resistant to most antibiotics used at the $4^{\text {th }}$ week of culture.

S. aureus isolates from burn wounds exhibited low sensitive against cefixime (22\%), amikacin (34.5\%) and cotrimoxazol $(36.6 \%)$. This was similar to report elsewhere (Kehinde et al., 2003). Vancomycin proved to the most effective antibiotic exhibiting $97.6 \%$ sensitivity to $S$. aureus. Other antibiotics sensitive to $S$. aureus were levofloxacin $(80.5 \%)$, chloramphenicol $(80.5 \%)$ and ciprofloxacin $(61.0 \%)$. CONS were least sensitive to cotrimoxazole $(8.3 \%)$, gentamycin $(16.7 \%)$ whereas all isolates of CONS was sensitive to vancomycin, this was similar to the previous study (Sloos and Dijkshoorn, 2000). In addition, they offered high sensitivity to levofloxacin $(66.7 \%)$ and ciprofloxacin $(58.3 \%)$. There were not significant changes in the sensitivity pattern of antibiotics of $S$. aureus. This may be the reason of decreasing the isolation of $S$. aureus from $2^{\text {nd }}$ week to $4^{\text {th }}$ week of culture. However, the sensitivity pattern of CONS decreased rapidly, which resulted in, complete resistant of six antibiotics in $2^{\text {nd }}$ week of culture and then remained fluctuated through the study period.

\section{CONCLUSION}

In conclusion, Gram negative bacteria were the dominating bacteria all over the study period specially $P$. aeruginosa and most of which were multidrug resistant. Amikacin was the drug of choice for most Gram negative bacteria and vancomycin was found to be effective against Gram positive bacteria ( $S$. aureus and coagulase negative staphylococci). Present investigation seem to be helpful in providing useful guidelines for choosing effective therapy against isolates from burn patients. 


\section{ACKNOWLEDGMENTS}

Authors would like to thank all the patients who agreed to participate in this study and made this research possible. Furthermore extend our gratitude to Bir Hospital for providing the necessary laboratory facility.

\section{REFERENCES}

Agnihotri, N., Gupta, V. and Joshi, R. M. 2004. Aerobic bacterial isolates from burn wound infections and antibiograms: a five-year study. Burns. 30: 241-243.

Alaghehbandan, R., Rossignol, A. and Lari, A. 2001. Pediatric burn injuries in Tehran, Iran. Burns. 27 (2): 115-118.

Atoyebi, O. A., Sowemimo, G. O. A. and Odugbemi ,T. 1992. Bacterial flora of burn wounds in Lagos, Nigeria: a prospective study. Burns. 18: 448-451.

Benson, F. 2001. Microbiological applications lab manual, 8th edn. McGraw-Hill, p. 50-70.

Bojary Nasrabadi, M. R. and Hajia, M. 2012. Multidrug-resistant Pseudomonas aeruginosa strains in Tehran Reference Burn Hospital, Tehran, Iran. Afr J of Microbio Res. 6 (7): 1393-1396.

Chalise, P. R., Shrestha, S. Sherpa, K., Nepal, U., Bhattachan, C. L. and Bhattacharya, S. K. 2008. Epidemiological and bacteriological profile of burn patients at Nepal Medical College Teaching Hospital. Nepal Med Coll J. 10 (4): 233-237.

Cheesbrough, M. 2006. District laboratory practice in tropical countries. Part II $2^{\text {nd }}$ edn. p. 80-84.

CLSI 2006. Performance standards for antimicrobial susceptibility testing, Fifteenth Informational Supplement, CLSI document M100-S16, Wayne, PA. USA. 26 (3).

Collee, J. G., Fraser, A. G., Marmion, B. P. and Simons, A. 1996. Mackie McCartney, Practical medical microbiology, $8^{\text {th }}$ edn. Churchil Livingstone, USA. p. 14.

Ekrami, A. and Kalantar, E. 2007. Bacterial infections in burn patients at a burn hospital in Iran. Indian J Med Res. 126: 541-4.

Erol, S., Altoparlak, U., Akcay, M. N., Celebi, F. and Parlak, M. A. 2004. Changes of microbial flora and wound colonization in burned patients. Burns. 30 (4): 357-61.

Guggenheim, M., Zbinden, R., Handschin, A. E., Gohritz, A., Altintas, M. A. and Giovanoli, P. 2009. Changes in bacterial isolates from burn wounds and their antibiograms: A 20-year study (1986-2005). Burns. 35: $553-560$

Hunt, J. L. and Purdue, G. F. 1992. The elderly burn patient. Am J Surg. 164: 472-476.

Kehinde, A. O., Ademola, S. A., Okesola, A. O., Oluwatosin, O. M. and Bakare, R. A. 2003. Pattern of bacterial pathogens in burn wound infection in Ibdan. Annals of Burns and Fire Disasters. XVII (n).

Komolafe, O. O., James, J., Kalongolera, L. and Makoka, M. 2003. Bacteriology of burns at the Queen Elizabeth Central Hospital, Blantyre, Malawi. Burns. 29: 235-238.

Lari, A. R. and Alaghehbandan, R. 2000. Nosocomial infections in an Iranian burn care center. Burns. 26(8): 737-740.

Lawrence, C. M. and Florencia, P. 2008. In Principle of Internal medicine, Harrison, 17th ed. McGraw-Hill, p. 835-836.
Lesseva, M. and Hadjiiski, O. G. 1996. Staphylococcal infections in the Sofia burn centre, Bulgaria. Burns. 22: 279-282.

Macedo, J. L. S. and Santos, J. B. 2005. Bacterial and fungal colonization of burn wounds. Mem Inst Oswaldo Cruz, Rio de Janeiro. 100(5): 535-539.

Nasser, S., Mabrouk, A. and Maher, A. 2003. Colonization of burn wounds in Ain Shams University Burn Unit. Burns. 29(3): 229-233.

Panjeshahin, M., Lari, A., Talei, A., Shamsnia, J. and Alaghehbandan, R. 2001. Epidemiology and mortality of burns in the South West of Iran. Burns. 27(3): 219-226.

Pruitt, B.A. 1984. The diagnosis and treatment of infection in the burn patient. Burns. 11: 79.

Saha. S. K., Muazzam, N., Begum, S. A., Chowdhury, A., Islam, M. S. and Parveen, R. 2011. Study on time-related changes in aerobic bacterial pattern of burn wound infection. Faridpur Med Coll J. 6(1): 41-45.

Santucci, S. G., Gobara, S. and Santos, C. R. 2003. Infections in a burn intensive care unit: experience of seven years. J Hosp Infect. 53: 6-13.

Silfen, R., Chemo-Lotan, M., Amir, A. and Hauben, D. 2000. Profile of the pediatric burn patient at the Schneider childrenís medical center of Israel. J Israel med association. 2(2): 138-141.

Singh, N. P., Goyal, R., Manchanda, V., Das, S., Kaur, I. and Talwar, V. 2003. Changing trends in bacteriology of burns in the burns unit, Delhi, India. Burns. 29:129-132.

Sloos, J. H. and Dijkshoorn, 2000. Septicemias caused by a strain of Staphylococcus haemolyticus exhibiting intermediate susceptibility to teicoplanin in multiple intensive care unit patients. J Antimicrob Chemother. 45(3): 400-411.

Ulku, A., Serpil, E., Fehmi, A. M. N. C. and Ayten, K. 2004. The time related changers of antimicrobial resistance patterns and predominant bacterial profiles of burn wounds and body flora of burned patients. Burns. 30: 660-664.

Vindenes, H. and Bjerknes, R. 1995. Microbial colonization of large wounds. Burns. 21: 575-9. 